\title{
PENGGUNAAN TEKNIK MURDER PENDEKATAN METAKOGNITIF UNTUK MENINGKATKAN PENALARAN MATEMATIS MAHASISWA PENDIDIKAN MATEMATIKA PADA MATAKULIAH GEOMETRI ANALITIK
}

\author{
Sri Asnawati ${ }^{1}$, Irmawati Liliana K.D ${ }^{2}$ \\ ${ }^{1}$ Pendidikan Matematika, FKIP, Universitas Swadaya Gunung Jati Cirebon \\ ${ }^{2}$ Pendidikan Matematika, FKIP, Universitas Swadaya Gunung Jati Cirebon \\ sriaasnawati88@gmail.com
}

\begin{abstract}
Abstrak. Tujuan dari penelitian ini adalah menelaah peningkatan kemampuan penalaran matematis mahasiswa yang memperoleh pembelajaran teknik MURDER pendekatan metakognitif dan mahasiswa yang memperoleh pembelajaran ekspositori pada materi garis dan lingkaran. Penelitian ini merupakan penelitian kuantitatif. Subjek penelitian adalah mahasiswa tingkat dua kelas $A$ dan kelas $B$ yang terdiri dari 35 mahasiswa. Metode pengumpulan data yang digunakan meliputi: (1) tes kemampuan penalaran matematis, (2) observasi, (4) dokumentasi. Data dianalisis menggunakan uji-t atau uji mann whitney. Hasil temuan penelitianin adalah: (1) Peningkatan kemampuan penalaran matematis mahasiswa yang memperoleh pembelajaran teknik MURDER pendekatan metakognitif lebih baik daripada peningkatan kemampuan penalaran matematis mahasiswa yang memperoleh pembelajaran ekspositori; (2) kualifikasi peningkatan penalaran matematis yang menggunakan pembelajaran teknik MURDER pendekatan metakognitif dan pembelajaran ekspositori masih dalam kategori sedang.
\end{abstract}

Kata kunci: Teknik MURDER, Pendekatan Metakognitif, Penalaran Matematis.

\section{PENDAHULUAN}

Matematika adalah salah satu subjek penting yang menentukan, dan berkontribusi terhadap pengembangan ilmu pengetahuan dan teknologi serta menunjang berbagai aktivitas keseharian umat manusia. Matematika juga menjadi landasan dalam berpikir, bernalar, dan menarik kesimpulan sehingga kita terbantu dalam memahami, menguasai, dan memecahkan berbagai permasalahan.

Dikarenakan matematika merupakan ilmu yang terstruktur, sistematis, dan mengembangkan sikap kreatif, sehingga pembelajaran matematika seyogianya memberi peluang kepada mahasiswa untuk mengembangkan sikap kritis, kreatif, dan inovatif. Pembelajaran matematika semestinya tidak sekadar menjadi kegiatan menghafal fakta, mengingat rumus, atau menguasai algoritma belaka, akan tetapi semestinya menjadi ajang aktivitas kreatif yang mendorong mahasiswa untuk berpikir dan bernalar.

Salah satu pendekatan pembelajaran yang dapat diterapkan pada penalaran matematis adalah pendekatan metakognitif, karena pendekatan ini berkaitan dengan kesadaran berpikir. Dengan kesadaran berpikir, mahasiswa dapat mengerjakan tugas-tugas khusus dan menggunakannya untuk mengontrol apa yang sedang mahasiswa kerjakan. Berpikir dan bernalar pada dasarnya adalah esensi dari kegiatan bermatematika (doing math).

Pembelajaran dengan pendekatan metakognitif menitikberatkan pada aktivitas belajar siswa, membantu dan membimbing siswa jika ada kesulitan, serta membantu siswa untuk mengembangkan kesadaran metakognisinya. Proses metakognisi menurut Elawar dalam Nindiasari (2004) adalah strategi pengaturan diri siswa dalam memilih, mengingat, mengenali kembali, mengorganisai informasi yang dihadapinya, 
dan menyelesaikan masalah. Sejalan dengan itu pula Jacob (2000:2) menyatakan bahwa metakognisi merupakan kesadaran berpikir sehingga kita dapat melakukan tugas-tugas khusus dan kemudian menggunakan kesadaran ini untuk mengontrol apa yang dikerjakan.

Geometri analitik pada dasarnya terbagi menjadi dua bagian besar, yaitu Geometri Analitik Bidang dan Geometri Analitik Ruang. Kedua bagian ini satu sama lainnya saling berhubungan erat tidak bisa dipisah-pisahkan. Kajian mata kuliah geometri analitik adalah bangun-bangun geometri yang diselesaikan dengan bantuan aljabar, sehingga mahasiswa diharapkan memiliki kemampuan berpikir logis, analitis, sistematis, kritis, dan kreatif, serta memiliki kemampuan bekerja sama. Kemampuan tersebut untuk menjadikan kondisi nyata bangun geometri menjadi konsep atau definisi secara aljabar, yang kemudian dibentuk menjadi sebuah teorema dan rumus. Kesimpulannya mahasiswa dalam membangun pengetahuan dalam mata kuliah geometri analitik harus didasarkan pada konteks nyata menggunakan kemampuan penalarannya, sehingga memiliki pola pikir bagaimana sebuah rumus atau teorema dibentuk.

Penguasaan materi geometri analitik yang masih rendah berdampak pada hasil belajar yang belum memuaskan. Kenyataan tersebut memerlukan perhatian dari pengajar untuk menggunakan pendekatan pembelajaran yang menyadarkan cara berpikir mahasiswa serta mampu meningkatkan pemahaman konsep dan penalaran mahasiswa terhadap materi geometri analitik. Dengan hal tersebut perlu adanya suatu upaya meningkatkan penalaran matematis mahasiswa, salah satunya yaitu pendekatan metakognisi.

Sehubungan dengan itu perlu adanya inovasi dalam pembelajaran yang mendukung adanya kemampuan bekerjasama. Bekerjasama adalah teknik pembelajaran kooperatif. Bekerja secara berkelompok, memberikan peluang kepada mahasiswa untuk dapat memecahkan masalah kompleks yang sering tidak terselesaikan apabila mahasiswa menyelesaikannya secara individu. Pada penelitian ini kemampuan bekerja sama dilakukan dengan teknik pembelajaran kooperatif MURDER (Mood, Understanding, Recall, Detect, Elaborate, Review). Berdasarkan perspektif psikologi kognitif, teknik MURDER memiliki fokus bagaimana manusia memperoleh, menyimpan, dan memproses apa yang dipelajarinya dan bagaimana proses berpikir dan belajar itu terjadi.

Berdasarkan pemaparan di atas, peneliti memandang perlu untuk mengkaji lebih dalam tentang penggunaan teknik MURDER dengan pendekatan metakognitif untuk meningkatkan penalaran matematis mahasiswa pendidikan matematika pada mata kuliah Geometri Analitik.

\section{METODE PENELITIAN}

Penelitian ini merupakan penelitian kuasi-eksperimen yang melibatkan dua katagori kelas sampel yang setara yaitu, kelas eksperimen dan kelas kontrol. Kelaskelas sampel tersebut dibentuk dengan menggunakan kelas-kelas yang ada, tidak dengan menempatkan secara acak subjeksubjek penelitian ke dalam kelas-kelas sampel. Pada kelas eksperimen menggunakan pembelajaran teknik MURDER pendekatan metakognitif, kelas kontrol menggunakan pembelajaran ekspositori.

Penelitian ini dilakukan pada semester ganjil tahun ajaran 2015/2016 Prodi Pendidikan Matematika Universitas Swadaya Gunungjati Cirebon.

Penelitian ini dilakukan terhadap mahasiswa tingkat dua Prodi Pendidikan Matematika Universitas Swadaya Gunungjati sampelnya dipilih dua kelas berdasarkan pertimbangan tertentu.

Adapun desain penelitian ini menggunakan desain sebagai berikut: Kelas Eksperimen $\quad: \mathrm{O}_{-}$_ $_{\mathbf{Z}} \mathrm{X}_{\mathbf{Z}} \mathrm{Q}$ Kelas Kontrol :O 
Ket. O : Pretes/Postes.

$\mathrm{X}$ :Pembelajaran inkuiri dengan etnomatematik

- - - : Subjek tidak dikelompokkan secara acak.

(Ruseffendi, 2005: 52)

Data penelitian ini berasal dari tes kemampuan penalaran matematis. Tes kemampuan penalaran matematis terdiri dari tes awal dan tes akhir. Tes awal diberikan dengan tujuan untuk mengetahui kesamaan kemampuan awal siswa pada kedua kelas dan digunakan sebagai tolak ukur peningkatan kemampuan penalaran sebelum mendapatkan perlakuan, sedangkan tes akhir diberikan dengan tujuan untuk mengetahui perolehan peningkatan kemampuan penalaran yang signifikan setelah mendapatkan perlakuan yang berbeda.

Tes kemampuan penalaran dibuat untuk mengukur kemampuan penalaran matematis mahasiswa tingkat dua mengenai materi yang sudah dipelajarinya. Adapun rincian indikator kemampuan penalaran yang akan diukur adalah sebagai berikut:1) mengajukan dugaan, $\quad 2$ ) melakukan manipulasi matematika, 3) menarik kesimpulan, menyusun bukti, memberikan alasan atau bukti terhadap kebenaran solusi, 4) menarik kesimpulan dari pernyataan, 5) memeriksa kesahihan argumen, 6) menemukan pola atau sifat dari gejala matematis untuk membuat generalisasi.

Instrumen penelitian pada penelitian ini berupa seperangkat soal tes kemampuan penalaran matematis. Soal penalaran matematis digunakan sebagai pretes dan postes yang hasilnya dianalisis.

\section{HASIL PENELITIAN DAN PEMBAHASAN}

Data penelitian diambil dari 35 mahasiswa, terdiri dari 18 mahasiswa kelas eksperimen yang mendapat pembelajaran teknik MURDER pendekatan metakognitif dan 17 mahasiswa kelas kontrol yang mendapat pembelajaran ekspositori. Pengolahan data menggunakan bantuan program SPSS. Berikut ini merupakan deskripsi pretes, postes dan $\mathrm{N}$-gain pada kelas eksperimen dan kelas kontrol.

Tabel 1. Statistik Deskriptif Kemampuan Penalaran Matematis

\begin{tabular}{ccc}
\hline Rata-rata & $\begin{array}{c}\text { Pre } \\
\text { test }\end{array}$ & N-gain \\
Kelas Eksperimen & 1,59 & 0,64 \\
Kelas Kontrol & 2,00 & 0,40 \\
Skor Maksimal Ideal = 16
\end{tabular}

Berdasarkan Tabel di atas, rerata gain sebesar 0,64 untuk kelas eksperimen dan kelas kontrol sebesar 0,40. Data tersebut menunjukkan bahwa peningkatan kedua kelas relatif sama dengan kualifikasi sedang, namun peningkatan kelas yang mendapat pembelajaran teknik MURDER pendekatan metakognitif lebih baik daripada kelas ekspositori. Dengan demikian dapat disimpulkan bahwa pembelajaran inkuiri dengan etnomatematik memberikan kontribusi yang lebih baik dalam perkembangan kemampuan penalaran matematis mahasiswa.

Analisis Skor Pretes Kemampuan Penalaran Matematis

Analisis skor pretes menggunakan uji kesamaan pretes. Uji kesamaan pretes bertujuan untuk memperlihatkan apakah kemampuan awal kedua kelas sama atau berbeda signifikan. Sebelumnya telah dilakukan uji prasyarat yaitu, kedua kelas tidak berdistribusi normal sehingga uji kesamaan rerata pretes menggunakan uji Mann Whitney.

Uji Kesamaan Rerata Pretes

Uji Kesamaan rerata pretes dilakukan untuk mengetahui apakah kemampuan awal pemahaman matematis siswa kelas eksperimen sama dengan kelas kontrol atau tidak. Berikut rangkuman hasil uji non parametrik Mann-Whitney pada taraf signifikansi $\alpha=0,05$. 
Tabel 2. Hasil Uji Mann Whitney Skor Pretes

\begin{tabular}{ccccc}
\multicolumn{5}{c}{ Kemampuan penalaran Matematis } \\
\hline Skor & Z & $\begin{array}{l}\text { Sig } \\
(2- \\
\text { tailed) }\end{array}$ & $\begin{array}{c}\text { Kesim- } \\
\text { pulan }\end{array}$ & $\begin{array}{l}\text { Kete- } \\
\text { rangan }\end{array}$ \\
Pretes & - & 0,280 & $\begin{array}{l}\mathrm{H}_{0} \\
\text { diterima }\end{array}$ & $\begin{array}{l}\text { Tidak } \\
\text { ada } \\
\text { perbe } \\
\text { daan }\end{array}$ \\
& $\begin{array}{l}0 \\
1,07\end{array}$ & & &
\end{tabular}

$H_{0}:$ rerata pretes kelas konvensional dan eksperimen tidak berbeda $\left(\mu_{e}=\mu_{k}\right)$

Nilai signifikansi uji Mann-Whitney untuk skor pretes $>\alpha=0,05$ yaitu, 0,280. Jadi, dapat disimpulkan bahwa tidak ada perbedaan yang signifikan antara skor pretes kelas eksperimen dan kelas kontrol. Artinya bahwa secara signifikan kemampuan awal penalaran matematis mahasiswa kelas eksperimen dengan kelas kontrol adalah sama.

Analisis Skor N-gain Kemampuan Penalaran Matematis

Hasil analisis pretes yaitu, kemampuan awal penalaran matematis antara mahasiswa kelas eksperimen dan kelas kontrol adalah sama. Menindaklanjuti hal tersebut dilakukan analisis rerata $\mathrm{N}$ gain. Analisis N-gain dilakukan untuk mengetahui peningkatan kemampuan penalaran matematis mahasiswa kelas mana yang lebih baik. Berikut disajikan rekapitulasi rerata $\mathrm{N}$-gain beserta klasifikasinya.

Tabel 3. Rerata dan Klasifikasi N-gain

Kemampuan Penalaran Matematis

\begin{tabular}{ccc}
\hline Kelas & $\begin{array}{c}\text { Rerata } \\
\text { N-gain }\end{array}$ & Klasifikasi \\
Etnomateatik & 0,64 & Sedang \\
Konvensional & 0,40 & Sedang \\
\hline
\end{tabular}

Tabel di atas menjelaskan bahwa skor $\mathrm{N}$-gain kelas eksperimen lebih tinggi dibandingkan rerata $\mathrm{N}$-gain kelas kontrol, meskipun keduanya termasuk dalam kategori sedang. Hal tersebut menunjukkan bahwa peningkatan penalaran matematis mahasiswa kelas eksperimen lebih baik daripada kelas kontrol namun, untuk meyakinkan apakah benar peningkatan kemampuan penalaran matematis mahasiswa kelas eksperimen lebih baik daripada kelas kontrol perlu dilakukan uji statistik lanjutan.

Adapun uji statistik yang digunakan untuk membuktikan hipotesis yang menyatakan "peningkatan kemampuan penalaran matematis mahasiswa yang memperoleh pembelajaran teknik MURDER pendekatan metakognitif lebih baik daripada pening katan kemampuan penalaran matematis mahasiswa yang memperoleh pembelajaran ekspositori' yaitu uji perbedaan rerata skor $\mathrm{N}$-gain.

\section{1) Uji Perbedaan Rerata Skor N-gain} Kemampuan Pemahaman Matematis

Berdasarkan hasil uji normalitas yang telah dilakukan sebelumnya didapat kesimpulan bahwa skor $\mathrm{N}$-gain kelas eksperimen dan kelas kontrol berdistribusi normal homogen. menindaklanjuti hal tersebut, dilakukan uji lanjutan dengan uji $t$.

Hipotesis penelitian yang diajukan adalah "Peningkatan kemampuan penalaran matematis mahasiswa yang memperoleh pembelajaran teknik MURDER pendekatan metakognitif lebih baik daripada peningkatan kemampuan penalaran matematis mahasiswa yang memperoleh pembelajaran ekspositori." Berdasarkan hipotesis penelitian, maka hipotesis statistik yang akan diuji adalah:

$\mathrm{H}_{0}$ : Tidak ada perbedaan peningkatan rerata kemampuan penalaran matematis mahasiwa antara mahasiswa yang mendapat pembelajaran teknik MURDER pendekatan metakognitif $\left(\mu_{1}=\mu_{2}\right)$.

$\mathrm{H}_{1}$ : Peningkatan rerata kemampuan penalaran matematis mahasiswa yang mendapat pembelajaran teknik MURDER pendekatan metakognitif lebih baik dibandingkan dengan mahasiswa yang mendapat pembelajaran ekspositori $\left(\mu_{1}>\mu_{2}\right)$. 
Dimana:

$\mu_{1}=$ rerata skor $\mathrm{N}$-gain kemampuan penalaran matematis mahasiswa yang mendapat pembelajaran teknik MURDER pendekatan metakognitif.

$\mu_{2}=$ rerata skor $\mathrm{N}$-gain kemampuan penalaran matematis mahasiswa yang mendapat pembelajaran ekspositori.

Kriteria: tolak $\mathrm{H}_{0}$ jika Signifikansi $>\alpha$.

Penelitian ini menunjukkan

beberapa temuan yang dianalisis berdasarkan perbedaan model pembelajaran yaitu, pembelajaran teknik Murder pendekatan metakognitif dan pembelajaran ekspositori, Berikut diuraikan pembahasan hasil penelitian:

\section{a. Model Pembelajaran}

Pada penelitian ini menggunakan dua jenis model pembelajaran yaitu pembelajaran teknik MURDER pendekatan metakognitif dan pembelajaran ekspositori. Berdasarkan hasil penelitian diperoleh bahwa hasil pembelajaran teknik MURDER pendekatan metakognitif dapat mengembangkan kemampuan penalaran matematis mahasiswa. Hal ini dibuktikan dengan skor $\mathrm{N}$-gain kemampuan penalaran mahasiswa yang memperoleh pembelajaran teknik MURDER pendekatan metakognitif sebesar 0,64, lebih tinggi daripada pembelaran ekspositori sebesar 0,40. Walaupun klasifikasi peningkatan penalaran matematis antara kelas yang mendapat pembelajaran teknik MURDER pendekatan metakognitif dan kelas ekspositori belum mencapai klasifikasi tinggi namun, berdasarkan hasil uji statistik diperoleh fakta bahwa peningkatan kemampuan penalaran matematis mahasiswa yang mendapat pembelajaran teknik MURDER pendekatan metakognitif lebih baik daripada siswa yang mendapat pembelajaran ekspositori.

Hasil yang telah diperoleh memberikan gambaran bahwa pembelajaran teknik MURDER pendekatan metakognitif terbukti memberikan kontribusi yang baik dalam mengembangkan kemampuan penalaran matematis mahasiswa sehingga, dapat disimpulkan bahwa pembelajaran teknik MURDER pendekatan metakognitif memiliki peranan yang lebih baik dalam mengembangkan kemampuan penalaran matematis mahasiswa.

Pembelajaran teknik MURDER pendekatan metakogmitif adalah pembelajaran yang memadukan teknik MURDER dan pendekatan metakognitif. Pembelajaran matematika dengan pendekatan metakognitif adalah pembelajaran yang menanamkan kesadaran bagaimana merencanakan, memonitor, serta mengontrol apa yang dilakukan untuk menentukan solusi dari suatu permasalahan. Adapum Pembelajaran matematika model kooperatif MURDER adalah pembelajaran yang memiliki enam langkah dalam pengimplementasiannya yaitu Mood, Understand, Recall, Detect, Elaborate dan Review. (Ball, 1997:22).

Peran dosen dalam pembelajaran MURDER pendekatan metakognitif adalah membimbing mahasiswa dalam merencanakan, memonitor, dan mengontrol apa yang sedang mahasiswa lakukan saat pembelajaran berlangsung. Peran dosen tersebut dijabarkan dalam aktifitas mahasiswa pada enam langkah yaitu, Mood, Understand, Recall, Detect, Elaborate dan Review. Saat pembelajaran berlangsung dengan menggunakan teknik MURDER pendekatan metakognitif mahasiswa akan banyak bekerja secara tim dan individu namun masih dalam satu kelompok. Ada kalanya mahasiswa melakukan aktifitas secara individu namun masih dibawah kontrol anggota kelompok lainya. Adapula aktifitas mahasiswa yang membutuhkan kerja secara tim saat mahasiswa diberikan lembar kerja yang berkaitan dengan penalaran matematis.

Soal-soal penalaran matematis mengharuskan mahasiswa memperoleh ide yang tidak biasa dalam memecahkan permasalahan yang dihadapi. Adapun aktivitas yang tercakup di dalam kegiatan penalaran matematis meliputi: menarik kesimpulan logis; menggunakan penjelasan 
dengan mengguanakn model, fakta, sifatsifat, dan hubungan; memperkirakan jawaban dan proses solusi; menggunakan pola dan hubungan; untuk menganalisis situasi matematik, menarik analogi dan generalisasi; menyusun dan menguji konjektur; memberikan contoh penyangkal (counter example); mengikuti aturan inferensi; memeriksa validitas argumen; menyusun argumen yang valid; menyusun pembuktian langsung, tak langsung dan menggunakan induksi matematik (Sumarmo, 2003).

Aktivitas mahasiswa selama kegiatan belajar dengan teknik MURDER pendekatan metakognitif meliputi mahasiswa diberi permasalah yang berkaitan dengan penalaran matematis. Permasalahan yang diberikan berkaitan dengan bagaimana mahasiswa menyusun argumen, membuktikan sebuah rumus pada materi garis dan lingkaran, mengaitkan sifat dan hubungan fakta untuk menganalisis sebuah permasalahan. Permasalahan penalaran yang diberikan haruslah menarik minat mahasiswa untuk memecahkan solusinya. Ketertarikan mahasiswa akan merangsang keingintahuan mahasiswa untuk memcahakan permasalahan yang dihadapinya.

\section{SIMPULAN DAN SARAN}

Simpulan

Peningkatan kemampuan penalaran matematis mahasiswa yang memperoleh pembelajaran teknik MURDER pendekatan metakognitif lebih baik secara signifikan daripada peningkatan kemampuan penalaran matematis mahasiswa yang memperoleh pembelajaran ekspositori namun, keduanya masih berkualifikasi sedang.

Saran

Berdasarkan hasil penelitian ini, selanjutnya diajukan saran-saran sebagai berikut: 1) model pembelajaran teknik MURDER pendekatan metakognitif dapat dijadikan alternatif pembelajaran bagi dosen dalam meningkatkan kemampuan penalaran matematis mahasiswa pada mata kuliah geometri analitik (materi garis dan lingkaran), 2) penerapan pembelajaran teknik MURDER pendekatan metakognitif pada penelitian ini terbatas pada pokok bahasan garis dan lingkaran, dan terbatas pada kemampuan penalaran matematis mahasiswa, sehingga diperlukan penelitian lebih lanjut pada pokok bahasan lainnya, dan pada kemampuan matematis lain dengan menyesuaikan dengan materi ajar. 3) hasil penelitian ini menunjukkan bahwa pembelajaran teknik MURDER pendekatan metakognitif memberikan peningkatan seignifikan pada kemampuan penalaran, namun masih dalam kualifikasi sedang sehingga menarik untuk dikaji lebih lanjut agar memberi kontribusi ke kualifikasi tinggi.

\section{DAFTAR PUSTAKA}

Hamzah, B.U. 2006. Orientasi Baru dalam Psikologi Pembelajaran. Jakarta:Bumi Aksara.

Jacob, C. 2000. Belajar Bagaimana untuk Belajar Matematika: Suatu Telaah Strategi Belajar Efektif. Prosiding Seminar Nasional Matematika: Peran Matematika Memasuki Millenium III. ISBN: 979-961520-8; 443-447. Jurusan Matematika FMIPA ITS. Surabaya.

Maulana. 2008. Pendekatan Metakognitif Sebagai Alternatif Pembelajaran Matematika untuk Meningkatkan Kemampuan Berpikir Kritis Mahasiswa PGSD, Jurnal Pendidikan Dasar [Diunduh 20 April 2015]

Sardiman. 2010.Interaksi dan Motivasi Belajar Mengajar.Jakarta : Rajawali Press

Sumarmo, U. 2003. Kemampuan Pemahaman dan Penalaran Matematika Siswa SMA dikaitkan 
dengan Kemampuan Penalaran Logik Siswa dan Beberapa Unsur Proses Belajar Mengajar. Bandung. UPI

Tim MKPBM. 2001. Strategi

Pembelajaran Matematika Kontemporer. Bandung: JICAUPI.
Uno, H.B.2007. Model Pembelajaran: Menciptakan Proses BelajarMengajar yang KreatifdanEfektif. Jakarta: PT Bumi Aksara.

Uno, H.B. 2009.Teori Motivasi \& Pengukurannya.Jakarta: BumiAksara. 